Original Research

\title{
Effects of Using Anode Biofilm and Cathode Biofilm Bacteria as Inoculum on the Start-up, Electricity Generation, and Microbial Community of Air-Cathode Single-Chamber Microbial Fuel Cells
}

\author{
Yang Jiawei, Cheng Shaoan* \\ State Key Laboratory of Clean Energy, Department of Energy Engineering, Zhejiang University, \\ Hangzhou, P.R. China
}

Received: 22 November 2017

Accepted: 2 January 2018

\begin{abstract}
Inoculum is critical for the start-up and performance of microbial fuel cells (MFCs). The effluent of mature MFCs is usually used as inoculum for the start-up of immature MFCs. However, the effluent of mature MFCs contains bacteria both from anode biofilm (ASB) and cathode biofilm (CSB). Here, ASB and CSB and their mixtures were used as inoculum in the start-up of MFCs in order to gain more insight into the influence of CSB on the start-up of MFCs. Compared to anode inoculum-enriched MFCs, using cathode inoculum reduced start-up time from $5 \mathrm{~d}$ to $3 \mathrm{~d}$. The time needed for scavenging oxygen was reduced from $900 \mathrm{~min}$ to $600 \mathrm{~min}$, maximum power density was $19 \%$ lower $\left(691 \mathrm{~mW} / \mathrm{m}^{2}\right.$ vs $823 \mathrm{~mW} / \mathrm{m}^{2}$ ), and the charge transfer resistance increased from $29.0 \Omega$ to $48.3 \Omega$. The decreased start-up time and power generation of cathode inoculum-enriched MFCs was attributed to the increasing abundance of Azospirillum (80.02\% vs. $12.68 \%$ ) and the decreasing abundance of Geobacter $(9.08 \%$ vs. $61.25 \%$ ). This research suggested that CSB in the effluent of mature MFCs, when used as inoculum, has a side-effect on the start-up of MFCs.
\end{abstract}

Keywords: microbial fuel cells, inoculum, anode biofilm, cathode biofilm, microbial community

\section{Introduction}

Microbial fuel cells (MFCs) have been considered a promising technology for wastewater treatment and energy recovery [1-2]. Unlike traditional fuel cells,

*e-mail: shaoancheng@zju.edu.cn
MFCs use bacteria as bio-catalysts to oxidize organic matter and convert chemical energy to electrical energy. These bacteria include anaerobic bacteria such as several Geobacteraceae strains [3], facultative bacteria such as Shewanella [4], and aerobic bacteria such as Pseudomonads [5]. Usually these bacteria can be inoculated from various alternative inoculum sources such as wastewater [6-9], heat-treated soil [10], garden 
compost [11], river water [12], and so on. Though microbial communities of the inoculums are abundant and diverse, the MFCs show strong selective effects for selecting electrochemical active bacteria and forming stable anodic microbial communities [8]. Normally it will take 10 to 15 days for the MFCs to reach the first maximum power production when using sludge or wastewater as inoculum [8]. For the fast start-up of MFCs, the effluent of mature MFCs is widely used as inoculum for the start-up of immature MFCs. The start-up time could be reduced to 3 to 5 days. It is also shown that in a two-chambered microbial electrolysis cell (MEC), the anode biofilm reformation has little influence on main functional groups of bacteria [9].

Air-cathode single-chamber microbial fuel cells have been considered an ideal configuration for practical application. In air-cathode single-chamber MFCs, cathode biofilm forms inevitably with the growth of anode biofilm. Previous research showed that cathode biofilm or oxygen-reducing biocathodes could form in $60-100 \mathrm{~h}$ [13-14], which is more rapid than the formation of the anode biofilm. Due to direct contact with the aircathode, aerobic and facultative anaerobic bacteria are more enriched on cathode biofilm, while the microbial population is maintained similarly to anode biofilm [15]. Therefore, bacteria form cathode biofilm also contains exoelectrogens as alternative inoculum. The effluent of mature MFCs contains bacteria both from anode biofilm (ASB) and cathode biofilm (CSB). When the effluent of mature MFCs was used as inoculum, it is necessary to know the effects of CSB on the start-up of MFCs. In this work, bacteria from anode biofilm and cathode biofilm were used to investigate the effects of relative abundance of facultative and aerobic bacteria on the performance of MFCs. Acclimation time, polarization tests, and electrochemical impedance spectroscopy (EIS) were used to evaluate MFC performance. The bacterial community was analyzed by the MiSeq Illumina sequencing technology.

\section{Material and Methods}

\section{MFC Configuration}

Air cathode cubic-shaped MFCs with a cylindrical chamber (working volume $10 \mathrm{~mL}$, electrode spacing $2 \mathrm{~cm}$ ) were constructed as previously described [16]. Anodes were made of graphite felt (Beijing Sanye Carbon Co., Ltd, China). Raw graphite felt was soaked into $0.1 \mathrm{~mol} / \mathrm{L} \mathrm{NaOH}$ and $\mathrm{HCl}$ solution successively, rinsed with deionized water until its $\mathrm{pH}$ value equaled 7 , and then dried and cut into circles of $4 \mathrm{~cm}$ in diameter (working area $7 \mathrm{~cm}^{2}$ ). The air cathodes were made of nickel foam containing an activated carbon catalyst [17]. Glass fiber was used to cover the water-side surface of the air-cathode to reduce the effect of oxygen on the anode biofilm.

\section{MFC Setup and Operation}

Anode biofilm and cathode biofilm were scraped form the anode and cathode of an MFC reactor that was inoculated with the primary clarifier overflow of the local wastewater treatment plant and that had operated for more than one year. The biofilms were swirled, resuspended in $50 \mathrm{mmol}$ phosphate-buffered solution (PBS, $2.45 \mathrm{~g} / \mathrm{L} \quad \mathrm{NaH}_{2} \mathrm{PO}_{4} \cdot \mathrm{H}_{2} \mathrm{O}, 4.58 \mathrm{~g} / \mathrm{L}$ $\mathrm{Na}_{2} \mathrm{HPO}_{4}, 0.31 \mathrm{~g} / \mathrm{L} \mathrm{NH}_{4} \mathrm{Cl}, 0.13 \mathrm{~g} / \mathrm{L} \mathrm{KCl}$ ), and diluted to the same cell density (based $\mathrm{OD}_{600}=0.07$ ). The anodic suspended bacteria, cathodic suspended bacteria, and their mixture (1:1) were referred to as ASB, CSB, and MSB, respectively. These three inocula were mixed with $50 \mathrm{mmol}$ PBS containing $2 \mathrm{~g} / \mathrm{L}$ acetate, $25 \mathrm{ml} / \mathrm{L}$ metal salts, and $10 \mathrm{ml} / \mathrm{L}$ vitamins [18] in a proportion of 1 to 1 and then used to inoculate MFCs (cycle 1). The corresponding MFCs were referred to as ASBMFC, CSB-MFC, and MSB-MFC. Starting from the second cycle, $50 \%$ of each MFC effluent was mixed with the same volume of $50 \mathrm{mmol}$ PBS containing $2 \mathrm{~g} / \mathrm{L}$ acetate, $25 \mathrm{ml} / \mathrm{L}$ metal salts, and $10 \mathrm{ml} / \mathrm{L}$ vitamins, and then used to refill each MFC. This solution was replaced until a similar output voltage was produced over two consecutive cycles (1000 $\Omega$ external resistance). The solution was then switched to $50 \mathrm{mmol}$ PBS containing $1 \mathrm{~g} / \mathrm{L}$ acetate, $12.5 \mathrm{ml} / \mathrm{L}$ metal salts, and $5 \mathrm{ml} / \mathrm{L}$ vitamins. The anode solution was replaced every $24 \mathrm{~h}$, forming one complete cycle of operation. All tests were conducted in a $30^{\circ} \mathrm{C}$ temperature-controlled room.

\section{Analysis}

Cell voltage across an external resistor was recorded every 20 mins using a multimeter with a data acquisition system (34970A, Agilent, U.S.). Electrochemical tests were conducted in cycles 11 and 30, showing consistent results. The polarization and power density curves were obtained by varying the external resistance from 1000 $\Omega$ to $80 \Omega$, with MFCs running for $20 \mathrm{~min}$ at each resistance. Electrochemical impedance spectroscopy was conducted on an electrochemical analyzer (Bio-Logic, Claix, France). A standard three-electrode configuration was used, with the anode serving as the working electrode, the cathode as the counter electrode, and an $\mathrm{Ag} / \mathrm{AgCl}$ electrode $(0.201 \mathrm{mV}$ vs SHE) as the reference electrode. The $\mathrm{Ag} / \mathrm{AgCl}$ reference was placed in close proximity to the anode. EIS tests were conducted at the circuit voltage under $1000 \Omega$ external resistance over a frequency range of $10^{5}-0.01 \mathrm{~Hz}$ with sinusoidal perturbation of $10 \mathrm{mV}$ amplitude.

The mixed culture biofilm was analyzed for the bacterial community by the MiSeq Illumina sequencing technology. DNA was extracted, amplified, and purified using a DNA isolation kit (PowerSoil DNA Isolation Kit, American). The paired primers in the variable regions V3-V4 (F: 5'-ACTCCTACGGGAGGCAGCAG-3', R: 5'-GGACTACHVGGGTWTCTAAT-3') were used for PCR amplification. The MiSeq Illumina sequencing 


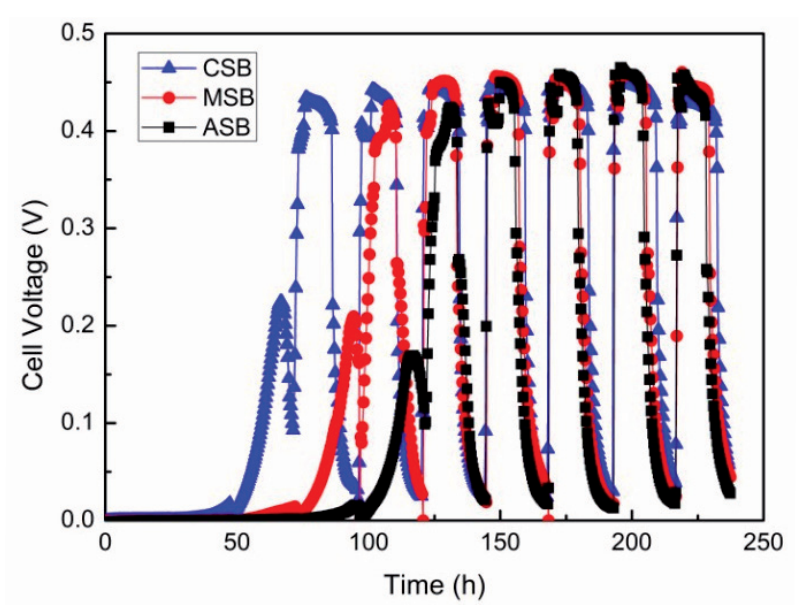

Fig. 1. Time-potential relationship in MFCs inoculated with $\boldsymbol{\Delta}$ ASB, the anodic suspended bacteria; $\bullet$ MSB, their mixture (1:1); and CSB, cathodic suspended bacteria.

was conducted and analyzed as described previously [19].

\section{Results}

\section{Electricity Production and Oxygen Consumption of MFCs during Start-up}

Inoculating MFCs with CSB required $50 \mathrm{~h}$ before a rapid increase of cell potential (Fig. 1). The reactors needed another $30 \mathrm{~h}$ to reach the first maximum power production and refuel three cycles before the cell voltages became reproducible in terms of maximum voltages. Using the MSB and ASB inocula, the time needed for rapid increase of cell potential was increased to $70 \mathrm{~h}$ and $100 \mathrm{~h}$, respectively, with a first maximum power cycle and reproducible cycle of voltage production requiring a number of cycles similar to that obtained with CSB.

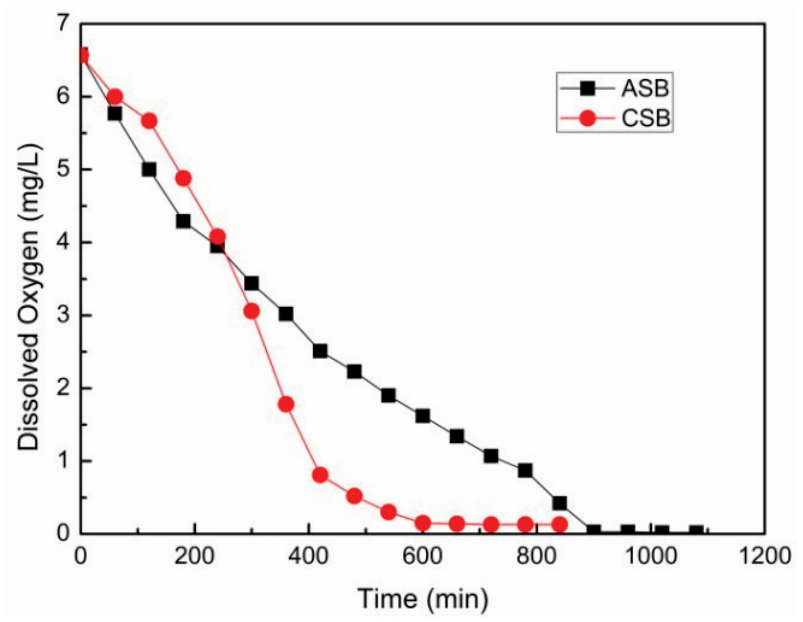

Fig. 2. Typical profiles of DO vs. time in a cycle during the startup period.

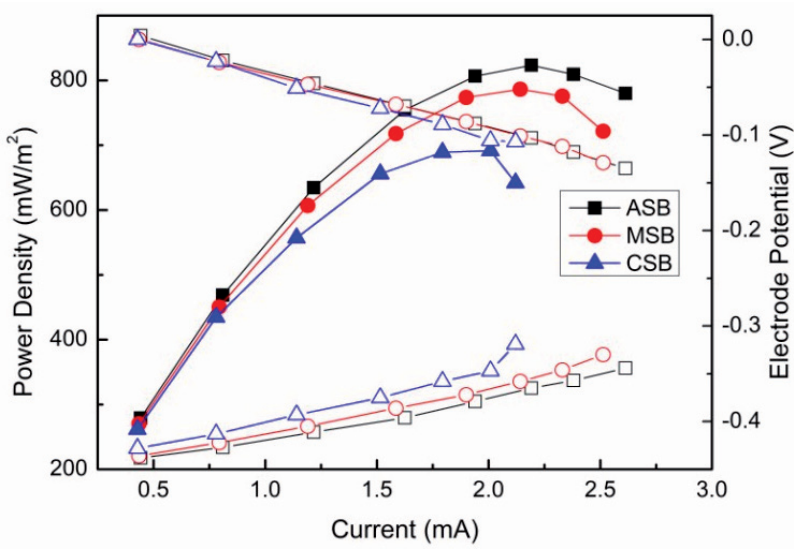

Fig. 3. Polarization curves of the MFCs inoculated with ASB, $\mathrm{MSB}$, and CSB; the hollow points represent the anode (down) and cathode (up) potential.

During the start-up stage, the typical profiles of dissolved oxygen (DO) vs. time in a cycle is shown in Fig. 2. Inoculating MFCs with ASB required $900 \mathrm{~min}$ before the DO reached $0 \mathrm{mg} / \mathrm{L}$. The oxygen consumption rate appeared to be independent of $\mathrm{DO}$, with a rate of $0.007 \mathrm{mg} \mathrm{DO} / \mathrm{L} / \mathrm{min}$. Using the CSB inoculum, the time needed for scavenging DO was reduced to $600 \mathrm{~min}$. The oxygen consumption rate first increased and then decreased when DO fell below $1 \mathrm{mg} / \mathrm{L}$

\section{Electricity Properties of MFCs}

The power density curve and polarization curves are shown in Fig. 3. The maximum power density of ASBMFC was $823 \mathrm{~mW} / \mathrm{m}^{2}$, which was $5 \%$ and $19 \%$ higher than MSB-MFC $\left(786 \mathrm{~mW} / \mathrm{m}^{2}\right)$ and CSB-MFC $\left(691 \mathrm{~mW} / \mathrm{m}^{2}\right)$, respectively. Electrode polarization curves showed that the increased power density was attributed to improved anode performance rather than cathode performance. When the cell current increased to more than $2 \mathrm{~mA}$, the anode potential of CSB-MFC rapidly increased $30 \mathrm{mV}$, while the anode potential of ASB-MFC and MSB-MFC increased $8 \mathrm{mV}$ and $12 \mathrm{mV}$. Further reducing the external resistor (increasing current), "power overshoot" was observed for CSB-MFC (data not shown), indicating severe electrode polarization of the CSB-MFC anode. Therefore, the maximum current obtained by CSB-MFC was $2.1 \mathrm{~mA}$, which was $19 \%$ and $24 \%$ lower than MSB-MFC (2.5 mA) and ASB-MFC (2.6 mA), respectively.

Anode EIS curves are shown in Fig. 4. An equivalent circuit of $R_{1}\left(R_{2} Q\right)\left(R_{3} Q\right)$ was used for estimating anode resistance, in which $R_{1}$ represents ohmic resistance, $R_{2}$ represents charge transfer resistance, and $R_{3}$ and $Q$ in parallel represent finite diffusion [20]. The total anode resistance of ASB-MFC was $52.1 \Omega$, which was $14 \%$ and $26 \%$ lower than MSB-MFC (60.6 $\Omega$ ) and CSB-MFC $(70.2 \Omega)$, respectively. The solution resistance $R_{1}$ and diffusion resistance $\mathrm{R}_{3}$ of all MFCs were $\sim 15 \Omega$ and $\sim 7$ $\Omega$, respectively. Therefore, the reduced charge transfer 


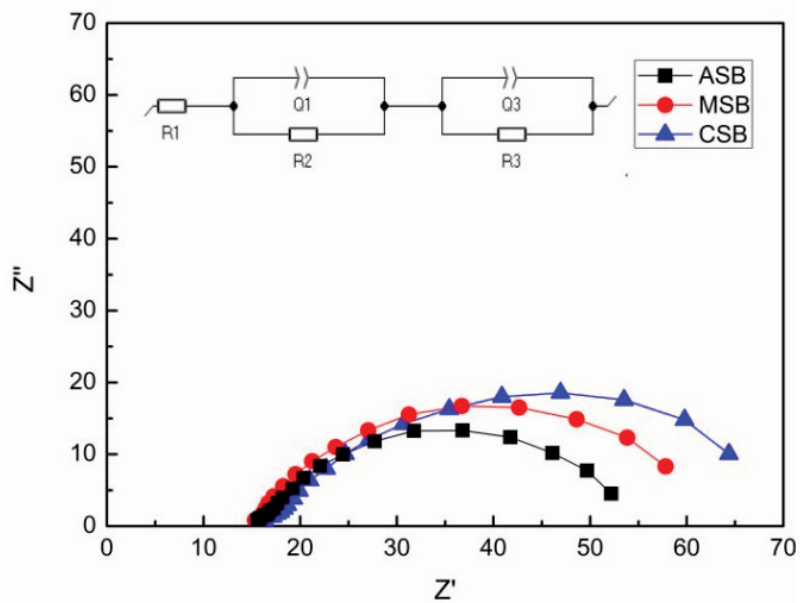

Fig. 4. Nyquist plots of EIS spectra of anode biofilm enriched with ASB, MSB, and CSB.

resistance $\mathrm{R}_{2}$ of ASB-MFC was credited for the improved anode performance. The charge transfer resistance $\mathrm{R}_{2}$ values for ASB-MFC, MSB-MFC, and CSB-MFC were $29.0 \Omega, 39.2 \Omega$, and $48.3 \Omega$, respectively, indicating better electrochemical kinetics from ASB-MFC.

\section{Microbial Community of Inocula and MFCs}

Composition and relative abundances of bacterial classes of ASB, CSB, ASB-MFC, and CSB-MFC are shown in Fig. 5. ASB and CSB were similar in bacterial populations, but vary from each other in the relative abundance of microbial communities. The dominating classes in ASB were Betaproteobacteria (relative abundances, 10.59\%), Deltaproteobacteria (13.02\%), Bacteroidia (27.02\%), Synergistia (14.35\%), and Actinobacteria (7.98\%). Meanwhile, the dominating classes in CSB were Betaproteobacteria (37.86\%), Alphaproteobacteria (22.21\%), and Flavobacteria (11.61\%). The compositions and dominating classes became more similar to each other in anode biofilms. The dominating classes in ASB-MFC and CSBMFC were Betaproteobacteria, Deltaproteobacteria, Alphaproteobacteria, and Bacteroidia. The main difference between ASB-MFC and CSB-MFC was the relative abundance of Deltaproteobacteria $(44.02 \%$ vs. 7.69\%) and Alphaproteobacteria (11.33\% vs. $63.57 \%$ ).

Table 1 shows the compositions and relative abundances of the bacterial genera of ASB, CSB, ASBMFC, and CSB-MFC. The dominating genera of ASB were Geobacter (19.08\%), Azoarcus (9.19\%), Blvii28 (37.83\%), and HA73 (11.69\%). The dominating genera of CSB were Pseudomonas (3.93\%), Azoarcus (64.01\%), Comamonas (5.23\%), and Ignavibacterium (3.09\%). The dominating genera in ASB-MFC and CSB-MFC were Geobacter, Azospirillum, Blvii28, and Dechloromonas. The most dominating genera, Geobacter and Azospirillum, comprised $70 \%$ to $90 \%$ of the relative abundances of anode biofilms.

\section{Discussion}

ASB was dominated by anaerobic bacteria. Geobacter is a typical anaerobic exoelectrogen. Blvii28 and HA73 were found to be anaerobic fermentation bacteria [21] and dominated in an anaerobic reactor [22]. Blvii28 tend to use complicated substrates such as peptone, yeast extract, maltose, and glucose, while some simple organic matters such as formic acid, acetate, and ethyl alcohol are not exploitable [21]. Thus, as the substrate provided was acetate, the high relative abundance of Blvii28 and HA7 might be caused by long-term operation in an anaerobic environment, in which they might be responsible for the degradation of metabolites and dead microorganisms. CSB was dominated by facultative and aerobic bacteria, which was consistent with Matteo Daghio's results [15] due to the micro-aerobic environment around the cathode. Azoarcus, which are facultative bacteria,

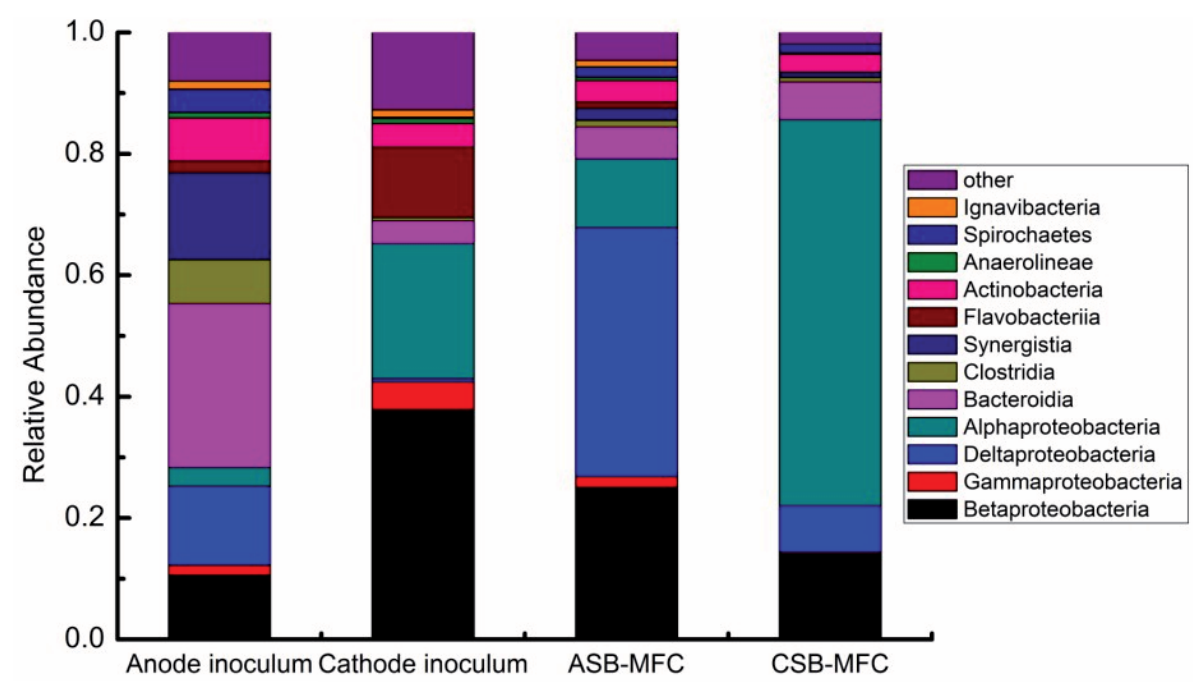

Fig. 5. Composition and relative abundances of bacterial classes in ASB, CSB, ASB-MFC, and CSB-MFC. 
Table 1. Relative abundances of bacterial OTUs based on the V3-V5 primer set ( $>0.5 \%$ of total population) in ASB, CSB, ASB-MFC, and CSB-MFC.

\begin{tabular}{|c|c|c|c|c|}
\hline Classification & $\mathrm{ASB} / \%$ & $\mathrm{CSB} / \%$ & ASB-MFC /\% & CSB-MFC $/ \%$ \\
\hline Geobacter & 19.08 & 0.90 & 61.24 & 8.98 \\
\hline Pseudomonas & 0.21 & 3.92 & 0.22 & 0.02 \\
\hline Azospirillum & 0 & 0.56 & 12.68 & 80.02 \\
\hline Azoarcus & 9.19 & 64.01 & 2.46 & 0.77 \\
\hline Acinetobacter & 0.02 & 0.68 & 0.10 & 0.05 \\
\hline Arcobacter & 0.93 & 0.40 & 0.06 & 0.02 \\
\hline Comamonas & 2.48 & 5.23 & 2.81 & 0.34 \\
\hline Blvii28 & 37.83 & 0.31 & 2.96 & 3.35 \\
\hline HA73 & 11.69 & 0 & 1.96 & 0.30 \\
\hline Fusibacter & 0.78 & 1.14 & 0.13 & 0.02 \\
\hline Dechloromonas & 0.80 & 1.95 & 5.98 & 2.66 \\
\hline Desulfovibrio & 0.95 & 0.15 & 0.13 & 0.07 \\
\hline Aminiphilus & 0.80 & 0.03 & 0.22 & 0.38 \\
\hline Fluviicola & 0.61 & 0 & 0.56 & 0.02 \\
\hline Anaerovorax & 1.59 & 0.15 & 0.52 & 0.22 \\
\hline Agrobacterium & 1.59 & 0.15 & 0.52 & 0.22 \\
\hline Mycobacterium & 0 & 0.19 & 1.89 & 1.48 \\
\hline Sphaerochaeta & 0.42 & 0 & 0.75 & 0.59 \\
\hline PSB-M-3 & 1.48 & 0.09 & 0.11 & 0.02 \\
\hline Thauera & 0.13 & 4.67 & 0.11 & 0.13 \\
\hline Sterolibacterium & 0.04 & 0 & 3.02 & 0.01 \\
\hline Candidatus & 0 & 0.56 & 0.09 & 0.01 \\
\hline Clostridium & 1.02 & 0 & 0.17 & 0.04 \\
\hline Treponema & 2.14 & 0 & 0.15 & 0.06 \\
\hline Corynebacterium & 0.83 & 0 & 0.01 & 0 \\
\hline B-42 & 0.47 & 1.36 & 0.09 & 0.02 \\
\hline Propionicimonas & 0.57 & 0 & 0 & 0.02 \\
\hline Paracoccus & 0.08 & 2.23 & 0 & 0 \\
\hline Ignavibacterium & 0.25 & 3.09 & 0.06 & 0.01 \\
\hline Devosia & 0.30 & 0.68 & 0.07 & 0.01 \\
\hline Parvibaculum & 0 & 1.48 & 0.16 & 0.01 \\
\hline Clavibacter & 0 & 3.59 & 0 & 0 \\
\hline Leptonema & 0.02 & 0.59 & 0.17 & 0.07 \\
\hline Hyphomonas & 0.21 & 1.08 & 0.01 & 0 \\
\hline Gemmatimonas & 0 & 0.80 & 0.01 & 0 \\
\hline Anaerolinea & 0.19 & 0 & 0.53 & 0.02 \\
\hline SJA-88 & 1.63 & 0 & 0.03 & 0.05 \\
\hline Methylosinus & 0.93 & 0 & 0.01 & 0 \\
\hline Dehalobacterium & 0.70 & 0 & 0 & 0 \\
\hline
\end{tabular}


have been reported in river sediment-inoculated MFCs and ethyl alcohol-fed MFCs [23-24]. Pseudomonas are aerobic bacteria, and they could use mediator for extracellular electron transfer [5]. Comamonas (5.23\%) [25] and Thauera (4.67\%) [26] are aerobic bacteria and facultative bacteria, respectively.

The time required for the rapid increase of cell potential with CSB-MFC was $50 \mathrm{~h}$ shorter than ASBMFC, indicating that inoculating with CSB could accelerate the growth and adsorption of microorganisms to form an anode biofilm. This might be attributed to the fast growth of aerobic and facultative bacteria, as the oxygen consumption rates in CSB-MFC were twotimes faster than in ASB-MFC during the start-up stage. When the anode biofilms formed, the relative abundance of Azospirillum sequencing in CSB-MFC was $80.02 \%$, while in ASB-MFC it was only $12.68 \%$. Azospirillum were considered to be facultative bacteria and had been reported in other MFC systems [27-28], and was suspected to have the ability to extracellularly transfer electrons [29]. Although the mechanism of extracellular electron transfer by Azospirillum has not been reported, the high relative abundance of Azospirillum in CSBMFC and ASB-MFC indicated that Azospirillum might be able to transfer electrons to the anode. The reduced acclimation time of CSB-MFC might be attributed to the fast growth of Azospirillum in the start-up stage.

The maximum power density of ASB-MFC was 823 $\mathrm{mW} / \mathrm{m}^{2}$ based on the anode surface area, comparable to other MFCs using a similar configuration $[16,30]$. The improved performance of ASB-MFC anode, relative to CSB-MFC, was attributed to the enhanced activity and number of redox proteins in the anodic biofilm, as shown by EIS results. The dominating bacterial genera in ASB-MFC and CSB-MFC were similar, while the main difference lay in the relative abundances of Geobacter (61.25\% vs. $8.98 \%$ ), Azospirillum (12.68\% vs. $80.02 \%$ ), Azoarcus (2.45\% vs. 0.77\%), Comamonas (2.81\% vs. $0.34 \%)$, HA73 (1.96\% vs. 0.30\%), Dechloromonas $(5.98 \%$ vs. $2.66 \%$ ), and Sterolibacterium (3.02\% vs. $0.01 \%)$. Geobacter is famous for its excellent electricity generation and long-range extracellular electron transfer [31] and used to be the dominating species in the anode biofilms of bioelectrochemical systems fed with acetate [19, 25, 32]. Comamonas is able to generate electricity with acetate as an electron donor in MFCs [25]. Dechloromonas has been widely found in MFC systems [33-34], known to be an electrochemically active microorganism [35]. Sterolibacterium is a genus of gram-negative bacteria from the family of Rhodocyclaceae, which belongs to the class of Betaproteobacteria and usually dominates in the anode biofilms of bioelectrochemical systems, and it shows an ability to extracellularly transfer electrons [36]. In general, the dominating genera in the anode biofilm of ASB-MFC were all known as electrochemically active microorganisms supporting the construction of highefficiency electrogenic biofilms. Considering that the maximum power density of CSB-MFC was only $19 \%$ lower than ASB-MFC, while the relative abundances of known exoelectrogens was $60 \%$ less than ASBMFC, there may have been other bacteria - perhaps Azospirillum - contributing to the electricity generation.

Although the relative abundance of the dominating bacterial communities of CSB and ASB varied from each other, the population of anode biofilms inoculated with CSB and ASB were similar. This might be attributed to the fact that CSB and ASB are both enriched in the same acetate-fed systems and well adapt to the environment. However, it also led to the fierce community competitions when use the mixture of CSB and ASB as inoculum. Although using $\mathrm{CSB}$ as inoculum will decrease the power density of MFCs, it may help for the construction of functional anode biofilms. For example, Azospirillum is a nitrogen-fixing bacterium that can potentially be applied in a nitrogen-fixing bioelectrochemical system [37].

\section{Conclusions}

ASB was dominated by anaerobic bacteria while CSB was dominated by facultative and aerobic bacteria. The time required for the rapid increase of cell potential with CSB-MFC was $50 \mathrm{~h}$ shorter than with ASB-MFC. The maximum power density of CSB-MFC was $19 \%$ lower than ASB-MFC $\left(691 \mathrm{~mW} / \mathrm{m}^{2}\right.$ vs. $\left.823 \mathrm{~mW} / \mathrm{m}^{2}\right)$. The reduced performance of the CSB-MFC anode was attributed to the decreased activity and number of redox proteins in anodic biofilm, as shown by EIS results. Community analysis of the anode biofilm of ASB-MFC and CSB-MFC showed that dominating genera in ASBMFC and CSB-MFC were Geobacter, Azospirillum, Blvii28, Comamonas, and Dechloromonas. ASB-MFC possessed higher abundances of Geobacter, Comamonas, and Dechloromonas, known as exoelectrogens, whereas CSB-MFC was abundant in Azospirillum, demonstrating that using anode inoculum performed better for the construction of high-efficiency electrogenic biofilm. This research suggested that $\mathrm{CSB}$ in the effluent of mature MFCs, when used as inoculum, has a side-effect on the start-up of MFCs. And Azospirillum species in the anodic biofilm might be exoelectrogen playing a role in electricity production.

\section{Acknowledgements}

This work was supported by the National Natural Science Foundation of China (No.51478414) and the National Key Research and Development Plan (2016YFB0600505).

\section{Conflict of Interest}

The authors declare no conflict of interest. 


\section{References}

1. FAN L., XU D., LI C., XUE S. Molasses wastewater treatment by microbial Fuel Cell with $\mathrm{MnO}_{2}$-Modified cathode. Pol. J. Environ. Stud. 25 (6), 2359, 2016.

2. HAI T., WEN-CHENG P., CHANG-FENG C., JIAN-PING $X$. . WEN-JUN H. Remediation of acid mine drainage based on a novel coupled Membrane-Free microbial fuel cell with permeable reactive barrier system. Pol. J. Environ. Stud. 25 (1), 107, 2016.

3. LOVLEY D.R., GIOVANNONI S.J., WHITE D.C., CHAMPINE J.E., PHILLIPS E.J., GORBY Y.A., GOODWIN S. Geobacter metallireducens gen. Nov. Sp. Nov., A microorganism capable of coupling the complete oxidation of organic compounds to the reduction of iron and other metals. Arch. Microbiol. 159 (4), 336, 1993.

4. CARMONA-MARTINEZ A.A., HARNISCH F., FITZGERALD L.A., BIFFINGER J.C., RINGEISEN B.R., SCHRÖDER U. Cyclic voltammetric analysis of the electron transfer of Shewanella oneidensis MR-1 and nanofilament and. Bioelectrochemistry. 81, 74, 2011.

5. RABAEY K., BOON N., HOFTE M., VERSTRAETE W. Microbial phenazine production enhances electron transfer in biofuel cells. Environ. Sci. Technol. 39 (9), 3401, 2005.

6. AHMED S., ROZAIK E., ABDELHALIM H. Performance of Single-Chamber microbial fuel cells using different Carbohydrate-Rich wastewaters and different inocula. Pol. J. Environ. Stud. 25 (2), 503, 2016.

7. SHENGKE Y., YANHUA W., YANG Z., HUIHUI L., WENKE W. Using Graphene/Polyaniline-Modified electrodes enhance the performance of Two-Chambered microbial fuel cells. Pol. J. Environ. Stud. 26 (3), 1233, 2017.

8. YATES M.D., KIELY P.D., CALL D.F., RISMANIYAZDI H., BIBBY K., PECCIA J., REGAN J.M., LOGAN B.E. Convergent development of anodic bacterial communities in microbial fuel cells. ISME J. 6, 2002, 2012.

9. LIU W., WANG A., SUN D., REN N., ZHANG Y., ZHOU J. Characterization of microbial communities during anode biofilm reformation in a two-chambered microbial electrolysis cell (MEC). J. Biotechnol. 157 (4), 628, 2012.

10. NIESSEN J., HARNISCH F., ROSENBAUM M., SCHRODER U., SCHOLZ F. Heat treated soil as convenient and versatile source of bacterial communities for microbial electricity generation. Electrochem. Commun. 8, 869, 2006.

11. PAROT S., DELIA M.L., BERGEL A. Acetate to enhance electrochemical activity of biofilms from garden compost. Electrochim. Acta. 53, 2737, 2008.

12. PHUNG N.T., LEE J., KANG K.H., CHANG I.S., GADD G.M., KIM B.H. Analysis of microbial diversity in oligotrophic microbial fuel cells using $16 \mathrm{~S}$ rDNA sequences. FEMS Microbiol. Lett. 1, 77, 2004.

13. LIU W., CHENG S., SUN D., HUANG H., CHEN J., CEN K. Inhibition of microbial growth on air cathodes of single chamber microbial fuel cells by incorporating enrofloxacin into the catalyst layer. Biosens. Bioelectron. 72, 44, 2015.

14. XIE S., LIANG P., CHEN Y., XIA X., HUANG X. Simultaneous carbon and nitrogen removal using an oxic/anoxic-biocathode microbial fuel cells coupled system. Bioresour. Technol. 102 (1), 348, 2011.
15. DAGHIO M., GANDOLFI I., BESTETTI G., FRANZETTI A., GUERRINI E., CRISTIANI P. Anodic and cathodic microbial communities in single chamber microbial fuel cells. New Biotechnol. 32 (1), 79, 2015.

16. LIU W., CHENG S., GUO J. Anode modification with formic acid: A simple and effective method to improve the power generation of microbial fuel cells. Appl. Surf. Sci. 320, 281, 2014.

17. CHENG S., WU J. Air-cathode preparation with activated carbon as catalyst, PTFE as binder and nickel foam as current collector for microbial fuel cells. Bioelectrochemistry. 92, 22, 2013.

18. LOVLEY D.R., PHILLIPS E.J.P. Novel mode of microbial energy metabolism: Organic carbon oxidation coupled to dissimilatory reduction of iron or manganese. Appl. Environ. Microb. 54 (6), 1472, 1988.

19. SUN D., CHENG S., WANG A., LI F., LOGAN B.E., CEN K. Temporal-Spatial changes in viabilities and electrochemical properties of anode biofilms. Environ. Sci.

20. YANG J., CHENG S., SUN Y., LI C. Improving the power generation of microbial fuel cells by modifying the anode with single-wall carbon nanohorns. Biotechnol. Lett. 39 (10), 1515, 2017.

21. SU X.L., TIAN Q., ZHANG J., YUAN X.Z., SHI X.S., GUO R.B., QIU Y.L. Acetobacteroides hydrogenigenes gen. Nov., Sp. Nov., An anaerobic hydrogen-producing bacterium in the family Rikenellaceae isolated from a reed swamp. Int. J. Syst. Evol. Micr. 64, 2986, 2014.

22. LANGILLE M.G., MEEHAN C.J., KOENIG J.E., DHANANI A.S., ROSE R.A., HOWLETT S.E., BEIKO R.G. Microbial shifts in the aging mouse gut. Microbiome. 2 (1), 50, 2014.

23. KIM J., JUNG S., REGAN J., LOGAN B. Electricity generation and microbial community analysis of alcohol powered microbial fuel cells. Bioresource Technol. 98 (13), $2568,2007$.

24. MEI X., GUO C., LIU B., TANG Y., XING D. Shaping of bacterial community structure in microbial fuel cells by different inocula. Rsc Adv. 5, 78136, 2015.

25. XING D., CHENG S., LOGAN B.E., REGAN J.M. Isolation of the exoelectrogenic denitrifying bacterium Comamonas denitrificans based on dilution to extinction. Appl. Microbiol. Biot. 85 (5), 1575, 2010.

26. SCHOLTEN E., LUKOW T., AULING G., KROPPENSTEDT R.M., RAINEY F.A., DIEKMANN H. Thauera mechernichensis sp. Nov., An aerobic denitrifier from a leachate treatment plant. Int. J. Syst. Bacteriol. 49, 1045, 1999.

27. SUN J., LI Y., HU Y., HOU B., ZHANG Y., LI S. Understanding the degradation of Congo red and bacterial diversity in an air-cathode microbial fuel cell being evaluated for simultaneous azo dye removal from wastewater and bioelectricity generation. Appl. Microbiol. Biot. 97 (8), 3711, 2013.

28. ZHOU S., HAN L., WANG Y., YANG G., ZHUANG L., HU P. Azospirillum humicireducens sp. Nov., A nitrogen-fixing bacterium isolated from a microbial fuel cell. Int. J. Syst. Evol. Micr. 63, 2618, 2013.

29. MA J., WANG Z., ZHANG J., WAITE T.D., WU Z. Cost-effective Chlorella biomass production from dilute wastewater using a novel photosynthetic microbial fuel cell (PMFC). Water Res. 108, 356, 2017.

30. ZHANG X., CHENG S., WANG X., HUANG X., LOGAN B.E. Separator characteristics for increasing performance of microbial fuel cells. Environ. Sci. Technol. 43 (21), 8456, 2009. 
31. BOND D.R., LOVLEY D.R. Electricity Production by Geobacter sulfurreducens Attached to Electrodes. Appl. Environ. Microb. 69, 1548, 2003.

32. TORRES C.I., KRAJMALNIK-BROWN R., PARAMESWARAN P., MARCUS A.K., WANGER G., GORBY Y.A., RITTMANN B.E. Selecting Anode-Respiring bacteria based on anode potential: Phylogenetic, electrochemical, and microscopic characterization. Environ. Sci. Technol. 43 (24), 9519, 2009.

33. SHEHAB N., LI D., AMY G.L., LOGAN B.E., SAIKALY P.E. Characterization of bacterial and archaeal communities in air-cathode microbial fuel cells, open circuit and sealedoff reactors. Appl. Microbiol. Biot. 97 (22), 9885, 2013.

34. KIM G.T., WEBSTER G., WIMPENNY J.W., KIM B.H., KIM H.J., WEIGHTMAN A.J. Bacterial community structure, compartmentalization and activity in a microbial fuel cell. J. Appl. Microbiol. 101 (3), 698, 2006.

35. HOLLOW N.R., BUSTARD M., WILKINSON D., WILLOUGHBY N. A bacterium in the genus Dechloromonas can reduce chromate(VI) and transfer electrons directly to the anode in a microbial fuel cell from a waste alcohol. J. Biotechnol. 131 (2), S237, 2007.

36. JANGIR Y., FRENCH S., MOMPER L.M., MOSER D.P., AMEND J.P., EL-NAGGAR M.Y. Isolation and characterization of electrochemically active subsurface delftia and azonexus species. Front. Microbiol. 7, 2016.

37. WONG P.Y., CHENG K.Y., KAKSONEN A.H., SUTTON D.C., GINIGE M.P. Enrichment of anodophilic nitrogen fixing bacteria in a bioelectrochemical system. Water Res. 64, 73, 2014. 